\title{
Priority Areas for Water Resources Conservation: Study Case Canal Guandu Watershed
}

\author{
Jonas Nunes Vieira, Helena Saraiva Koenow Pinheiro \\ Universidade Federal Rural do Rio de Janeiro - UFRRJ, Brazil \\ Mateus Marques Bueno (Corresponding author) \\ Instituto Federal de Educação, Ciência e Tecnologia de Minas Gerais - IFMG, Brazil \\ Waldir de Carvalho Junior, Nilson Rendeiro Pereira \\ Empresa Brasileira de Pesquisa Agropecuária - EMBRAPA Solos, Brazil \\ Daniel Costa de Carvalho \\ Universidade de Brasília - UNB, Brazil \\ Paula Fernanda Chaves Soares \\ Universidade Iguaçu - UNIG, Brazil
}

Received: Aug. 10, $2020 \quad$ Accepted: Sep. 10, $2020 \quad$ Published: Sep. 25, 2020

doi:10.5296/ast.v9i1.17502 URL: https://doi.org/10.5296/ast.17502

\begin{abstract}
The environmental resilience is strictly dependent of water availability. The identification of priority areas is important to conservation aid land-use planning and urban expansion, conservation, and policy strategy. The goal was to identify priority areas aiming water provision and environmental conservation at the "Canal do Rio Guandu" watershed in Rio de Janeiro, Brazil. To address the goal four micro-basins included in the watershed were selected to optimize collect field data and create the criteria to define the priority levels. Based on prior literature, legacy and field data, an assessment method was proposed based on map algebra with support of Geographical Information System, gathering professional tacit knowledge with spatial data to support the selection of strategic areas. The approach based on was successful to select primarily priority areas and can contribute to regulate the local policies, pointing out areas that can connect legally protected areas with forested fragments,
\end{abstract}


which presents great importance to urban and rural supply.

Keywords: morphometry, hydrography, permanent preservation areas

\section{Introduction}

The environmental issues related with impacts of global climate changes could be reduced by assessment of land capability and adequate soil management (Mora, 2019). The pressure over natural resources motivates research addressing relevant environmental information that aids resources managers (Honda and Durigan, 2017). In this sense, the selection of priority areas to environmental preservation presents great importance to improve strategic actions for water resources conservation, guiding policy efforts and land use planning (Mello et al., 2018).

Priority areas to preserve and conserve natural resources may have objectives such as water production, maintenance, and storage (Honda \& Durigan, 2017). Therefore, to select priority areas for water provision and environmental conservation is necessary combine several field data and legacy data by using Geographical Information System (GIS) and geoprocessing tools (Mello et al., 2018; Vettorazzi \& Valente 2016). This integration is based on a multicriteria evaluation aiding the interpretation of soils and water behavior in watersheds, based on field observation and digital surface models, as well physiographical parameters, and drainage patterns. Map algebra is widely used as a tool for environmental fragility analyzes, showing the effectiveness on watershed assessment and landscape use planning (Ayalew and Selassie, 2015).

The identification of areas with potential for preservation and provision of water sources is an important step towards environmental safety, especially in significantly deforested biomes such as the Atlantic Forest (Scarano and Ceotto, 2015). To evaluate a potential methodology to select priority areas to water provision and environmental conservation is necessary a representative and relevant territorial unit, as a watershed (Bueno et al., 2020). Areas with great landscape variability comprising since mountains at floodplains and with socioeconomical importance should be selected to represent all environmental conditions at the watershed.

In addition, areas with potential for preservation of springs, hills, steep areas, and those with the potential to connect forested fragments were specially evaluated (Brancalion et al., 2016). Potential interventions in these areas could promote the maintenance and expansion of ecosystem services to the benefit of local and surrounding populations (Bagstad et al., 2013.

The research goals were characterizing the physiographical parameters, geomorphological and hydrological aspects of a group of micro-basins inserted in the Canal do Rio Guandu watershed. Also, these areas are classified according with the priority to water provision and environmental conservation. Moreover, this study contributes to provide relevant information to the water management committee, research centers, universities, and society in general.

\section{Method}

The study was developed at the Canal do Rio Guandu watershed (BHCRG), inserted at the 


\section{Ml Macrothink}

Hydrographic Region II (Guandu Region), according the limits established by Cope Construções Projetos e Engenharia Ltda. (available at: agevap.org.br/downloads). The BHCRG watershed has area with approximately 32,000 hectares, and presents distinct geomorphological features placed at the transition of mountainous area to coastal plains, comprising the municipalities of Queimados, Japeri, Paracambi, Seropédica, Nova Iguaçu and Rio de Janeiro. At the boundaries of the BHCRG are located the Tinguá Biological Reserve (REBIO do Tinguá) and Mendanha State Park (PE Mendanha), both protected areas according Brazilian environmental law.

A database with the available environmental data (topographic data, political and geographical boundaries, thematic maps, satellite images) built based on several governmental open sources as BDGEx (2011), SIGA-Guandu (2010), IBGE (2010), Embrapa geodatabase (2013), and MMA (2013).

Preliminary maps highlighting the access roads, land use types, and hydrography were used to aid the field campaigns and to select representative micro-basins. Four micro-basins were selected denominated as MBH1, MBH2, MBH3 and MBH4 (Figure 1) based on land use types and environmental representativeness regarding landscapes and soil types. These basins were selected for further investigation and field sample data.
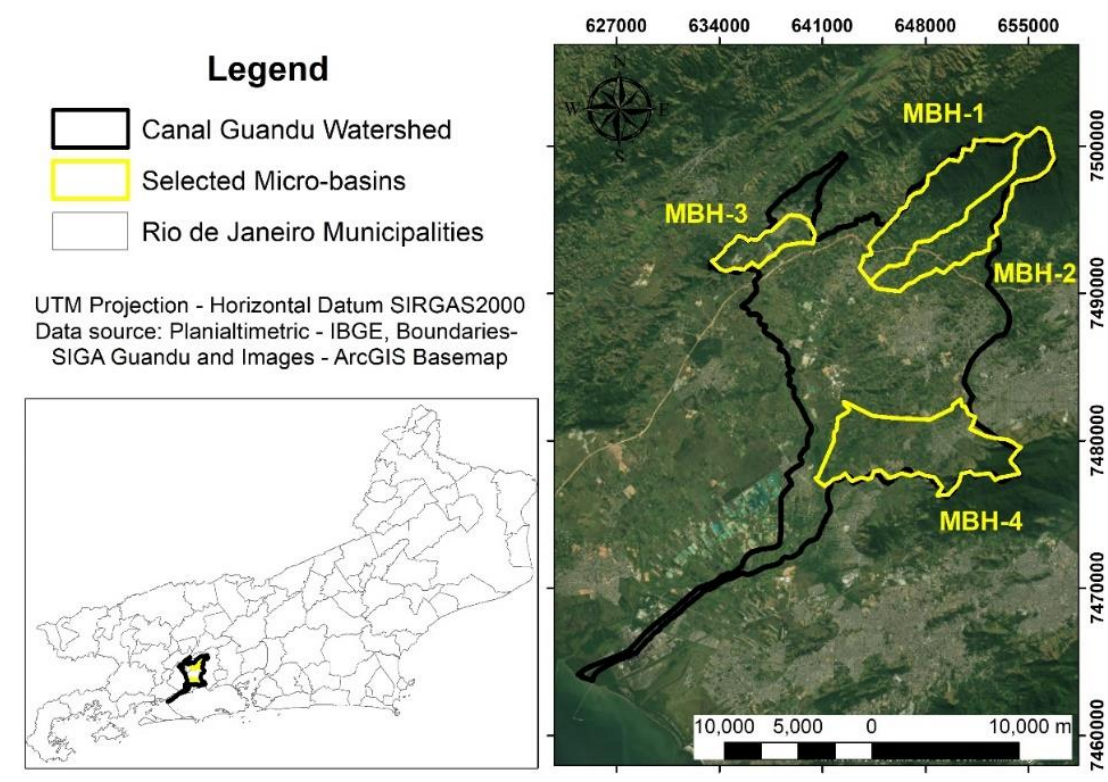

Figure 1. Location of study area (Canal do Rio Guandu watershed) and the four micro-basins selected

The hydrographic characterization of the micro-basins was based in physiographical parameters and drainage patterns classified as purposed by Rai et al (2017a). In order to evaluate the geometric characteristics, as proposed by Alves \& Castro (2016) and presented at Table 1, comprising: Area (Ar), Perimeter (Pe), drainage density (Dd), roughness index (Ir), Compactness coefficient $(\mathrm{Cc})$ and Circularity Index (Ic). The $\mathrm{Cc}$ is the relationship between the perimeter of the basin evaluated and the circumference of a circle of area equal to that of the same. The calculated number does not depend on the area under consideration, depending 
only on the shape of the basin. Simultaneously with Cc, Ic tends to a binary pair $(1,1)$ as the basin approaches the circular shape.

Regarding the parameters of the drainage network, the Drainage Density (Dd), Roughness Index (Ir) and Coefficient of Maintenance $(\mathrm{Cm})$ were calculated, according Table 1 . The Dd can be defined as the average concentration of drainage extension per unit area. Combining the Dd with topographic factors we obtain the Ir expressing as a dimensionless number. The Ir index represents the relation between the Dd and the topographic amplitude, and high values means more susceptibility to degradation processes, due the hilly and lengthy slopes (Calil et al., 2012). The $\mathrm{Cm}$ is calculated by the inverse relation of $\mathrm{Dd}$ and provides the minimum area required for the maintenance of one (1) meter of flow channel (Schumm, 1956).

Table 1. Morphometric parameters used to characterize the micro-basin's characterization

\begin{tabular}{lccc}
\hline Characteristics & Morphometric parameters & Equation & Unit \\
\hline Geometrics & Area & - & $\mathrm{km}^{2}$ \\
Geometrics & Perimeter & - & $\mathrm{km}$ \\
Geometrics & Circularity index & $12.56^{*} \mathrm{~A} / \mathrm{P}^{2}$ & Dimensionless \\
Geometrics & Compactness coefficient & $0.28^{*} \mathrm{P} / \sqrt{\mathrm{A}}$ & Dimensionless \\
Drainage network & Roughness index & $\mathrm{Dd} * \mathrm{H}$ & Dimensionless \\
Drainage network & Drainage density & $(\Sigma \mathrm{L}) / \mathrm{A}$ & $\mathrm{km} / \mathrm{km}^{2}$ \\
Drainage network & Coefficient of maintenance & $(1 / \mathrm{Dd})^{*} 1000$ & $\mathrm{~m} / \mathrm{m}$ \\
\hline
\end{tabular}

Adapted from Rai et al., (2017a) and Aher et al., (2014)

The spatial analysis procedures including the calculation of morphometrical parameters were performed in ArcGIS Desktop v.10.5 and SAGA-GIS (available at: http://www.saga-gis.org). The numerical surface models were processed by using the extension Spatial Analyst Tools in ArcGIS. All the surface models, including the Digital Elevation Model (DEM) were created with 10 meters of spatial resolution and projected in metric coordinate system (Universal Transverse Mercator- UTM) using SIRGAS2000 as horizontal datum.

A field campaing was executed to subsidize the creation of thematic maps and definition of priority criteria for the assessment of potential areas to water provision and environmental conservation. Soil data were obtained through profile description and were collected to analytical characterization. The soil classification was based on the Brazilian Soil Classification System (Santos et al, 2018) and the World Reference Base for Soil Resources - 
WRB System (IUSS, 2014).

The soil map units were simplified at tree types of soil associations, respecting the concepts preconized by Santos et al. (2018) and IBGE (2015). The characterization was based on soil profile description and the spatialization considered environmental characteristics related with soil forming factors, where the climate, the relief, the organisms, the parental material, and the time are responsible for soil differences (Neto et al., 2018). The main factors considered were the TWI and the elevation (DEM) that reflected the differences regarding soil drainage, corroborating field observations. The tree map units defined regarding landscape patterns and soils behavior face the potential to water provision and vegetation establishment are presented in the items below:

\section{- Unit 1: GX + CY-Association of Haplic Gleysols and Fluvisols.}

Refers to lowlands and floodplains which have sediments coming from higher areas of the landscape. They are clay soils, poorly drained and occurring in smooth relief. The mean uses are pasture and other cultures (e.g. Manihot esculenta), and urban areas. Occupy areas below $40 \mathrm{~m}$ of altitude. The risk of flooding is their principal limitation facing the urban expansion upon these areas. These areas are important to the creation of ecological corridors linking forest fragments, due their environmental diversity, necessary to the wildlife maintenance.

\section{- Unit 2: PA + CX (LVA)- Association of Acrisols and Haplic Cambisols with inclusions of Haplic Ferralsols (Dystric).}

Consists of clay soils well drained areas that occur in gentle wavy relief, between 40 and $100 \mathrm{~m}$ of altitude. Comprises low hills with rounded summits, where Acrisols are the most common soil type. These are occupied by pastures and certain urban areas and might present aptitude to rising farms, and at that hilly areas the reforestation and conservancy of the existent vegetation are most strongly indicated.

\section{- Unit 3: CX + RL + AR- Association of Haplic Cambisol, Leptosols and Rock Outcrops}

Occurs mostly at the higher levels of the landscape, above $100 \mathrm{~m}$, with structured relief according of the geology. In general, under the ARF, occurs the water springs and natural reserves (e.g. REBIO Tinguá). The lithology associated to this unit comprises gneiss and granite rocks. This unit is primarily indicated to preservation and reforestation due their environmental fragility and their relevance to the water sources.

The phytophysiognomies were classified based on visual analysis in situ according to the criteria established by the Technical Manual of Brazilian Vegetation (IBGE, 2012), at two types of Atlantic Rain Forest (ARF), comprising Submontane and Lowland Dense Ombrophylous Forests. The successional stage of the natural fragments was defined by the qualitative parameters of the vegetation, as described in CONAMA Resolution N 006/1994 (BRASIL, 1994). The land use cover map was adapted from legacy data (SIGA Guandu database), and reflects the urban areas, the pasture and agricultural uses and the conservation units where still remaining fragments of natural vegetation. 
The geomorphological parameters comprised elevation (DEM), slope, aspect, and topographic wetness index (TWI), represented as numerical surface models, and corroborated by field data. The correlation between ground control points (field data), surface models and legacy data support the definition of all priority criteria adopted in this approach.

An evaluation matrix (Table 2) was created to organize the criteria used in the assessment of priority areas for the maintenance of water sources. The selection of priority areas was based on secondary data, handled as described below, and primary information obtained from field visits and laboratory analyzes.

Table 2. Evaluation matrix and criteria to define priority areas for water provision and environmental conservation

\begin{tabular}{|c|c|c|c|}
\hline Item & Potential & Aspect $\left({ }^{\circ}\right)$ & Slope $(\%)$ \\
\hline & High & South (135-225) & $\leq 5$ \\
\hline \multirow[t]{4}{*}{ Relief } & Medium & East/west (5-135/225-315) & 45 \\
\hline & Low & North (315-45) & $>45$ \\
\hline & & Class & Drainage phase \\
\hline & High & $\begin{array}{l}\text { Ferralsols, Cambisols }(\mathrm{DEM}>100 \mathrm{~m} \text { e } \\
\qquad \mathrm{TWI}<5)\end{array}$ & $\begin{array}{l}\text { Well to moderately } \\
\text { drained }\end{array}$ \\
\hline \multirow[t]{4}{*}{ Soils } & Medium & $\begin{array}{l}\text { Cambisols, Acrisols (DEM 40-100m e TWI } \\
\text { 5-7) }\end{array}$ & $\begin{array}{l}\text { Well to moderately } \\
\text { drained }\end{array}$ \\
\hline & Low & Hydromorphic soils (DEM<40m e TWI>7) & Poorly drained \\
\hline & & Use Type & $\begin{array}{c}\text { Proximity of } \\
\text { protected areas }\end{array}$ \\
\hline & High & $\begin{array}{l}\text { Original formations (sandbank vegetation, } \\
\text { forest, mangrove) }\end{array}$ & $0-100 \mathrm{~m}$ \\
\hline \multirow[t]{2}{*}{ Vegetation } & Medium & $\begin{array}{c}\text { Vegetation secondary in initial regeneration } \\
\text { and natural grasslands }\end{array}$ & $100-200 \mathrm{~m}$ \\
\hline & Low & Agricultural and other uses & $>200 \mathrm{~m}$ \\
\hline
\end{tabular}

The criteria related to soils characteristics respects the concepts adopted by Santos et al (2018) and IBGE (2015), where the definition of different soil map units considers landscape and 
drainage characteristics. Soil information gather relief aspects to define conservation priority, showed to be trustable and necessary, particularly on watershed evaluations (Padilha et al, 2017; Oliveira et al, 2012; Silveira et al, 2015).

Well drained soils were separated in two groups once they present distinct depth, different potential to produce water, and favorable conditions to grow the natural vegetation (originally ARF). In other hand, despite the facility to storage water, to the hydromorphic soil types were assigned a low potential to intervention regarding land use management. The soil map was created by map algebra adopting as parameters the digital elevation model (DEM) and topographic wetness index (TWI), as suggested by pedologists along the field campaign, once these variables influences the soil drainage.

Regarding the topographic aspects, high potential was designed to smooth slopes (slope values less than five percent), corresponding to flat summits and floodplains. Areas with rounded shape and low altimetric and slope gradient, were defined as medium potential, and to slopes higher than $45 \%$ usually related with escarpments at the watershed divisors were assigned low potential. The topographic parameters also considered the 'aspect' that represents the slope direction regarding geographic position. In the south hemisphere the slopes placed at the south and southern directions receive more natural humidity from the coastal winds, when compared with the north and northwest directions (Pezzopane et al.,2001; Arias et al., 2015).

The analysis of priority areas to water provision and environmental conservation considered the Permanent Protected Areas (APP) and Conservation Units (UC), established by Brazilian environmental law as possible sources providing vegetation spread, in this sense supporting the establishment of ecological corridors. The source of this data was the SIGA Guandu database, and environmental ministry database (Ministério do Meio Ambiente - MMA). A thematic map representing the priority conservation regarding the proximity of protected areas, according Brazilian law, was created based on UC, and APP areas. The distance from the protected areas was calculated in meters and classified in three classes, being the closest distance from APP and UC with high priority, and analogously, the longest distances were classified as low priority (Table 2). Urban areas were previously assumed as low priority areas.

\section{Results}

The BHCRG is considered as a large natural unit due the catchment area and perimeter (Table 3 ). The representative micro-basins assigned to more detailed studies and field sampling (MBH-1; 2; 3; and 4) presents, respectively, 11.4\%; 9.2\%; 3.6\% e $15.5 \%$ of total catchment area of BHCRG. 
Table 3. Morphometric parameters of BHCRG watershed and four micro-basins selected

\begin{tabular}{|c|c|c|c|c|c|}
\hline \multirow{2}{*}{ Morphometric parameters } & \multirow{2}{*}{ BHCRG } & \multicolumn{4}{|c|}{ Micro-basins } \\
\hline & & 1 & 2 & 3 & 4 \\
\hline Drainage pattern & & $\mathrm{D}$ & $\mathrm{D}$ & $\mathrm{D}$ & $\mathrm{D}$ \\
\hline Area $\left(\mathrm{km}^{2}\right)$ & 323.44 & 36.96 & 29.79 & 11.55 & 50.05 \\
\hline Perimeter (km) & 120.70 & 33.48 & 37.32 & 17.89 & 41.27 \\
\hline Compactness coefficient (Cc) & 1.88 & 1.54 & 1.91 & 1.47 & 1.63 \\
\hline Circularity index (Ic) & 0.28 & 0.41 & 0.27 & 0.45 & 0.37 \\
\hline Drainage density $\left(\mathrm{km} / \mathrm{km}^{2}\right)(\mathrm{Dd})$ & 2.47 & 2.78 & 2.58 & 3.44 & 2.91 \\
\hline Roughness index (Ir) & 3.95 & 3.92 & 4.08 & 1.25 & 2.70 \\
\hline Coefficient of maintenance $\left(\mathrm{m}^{2} / \mathrm{m}\right)(\mathrm{Cm})$ & 404.86 & 359.71 & 387.60 & 290.70 & 343.64 \\
\hline \multicolumn{6}{|c|}{$* \mathrm{D}=$ Dendritic } \\
\hline \multicolumn{6}{|c|}{$\begin{array}{l}\text { The relief conditions were defined based on numerical surface models and corroborated by } \\
\text { field observations, which showed to be useful to subsidize the definition of the parameters } \\
\text { used to select priority areas. Geomorphology directly reflects relief and soils interaction, } \\
\text { where the elevation (meters), the slope (percentage), the topographic wetness index } \\
\text { (dimensionless) and the aspect (degrees), were relevant (Figure 2). }\end{array}$} \\
\hline
\end{tabular}



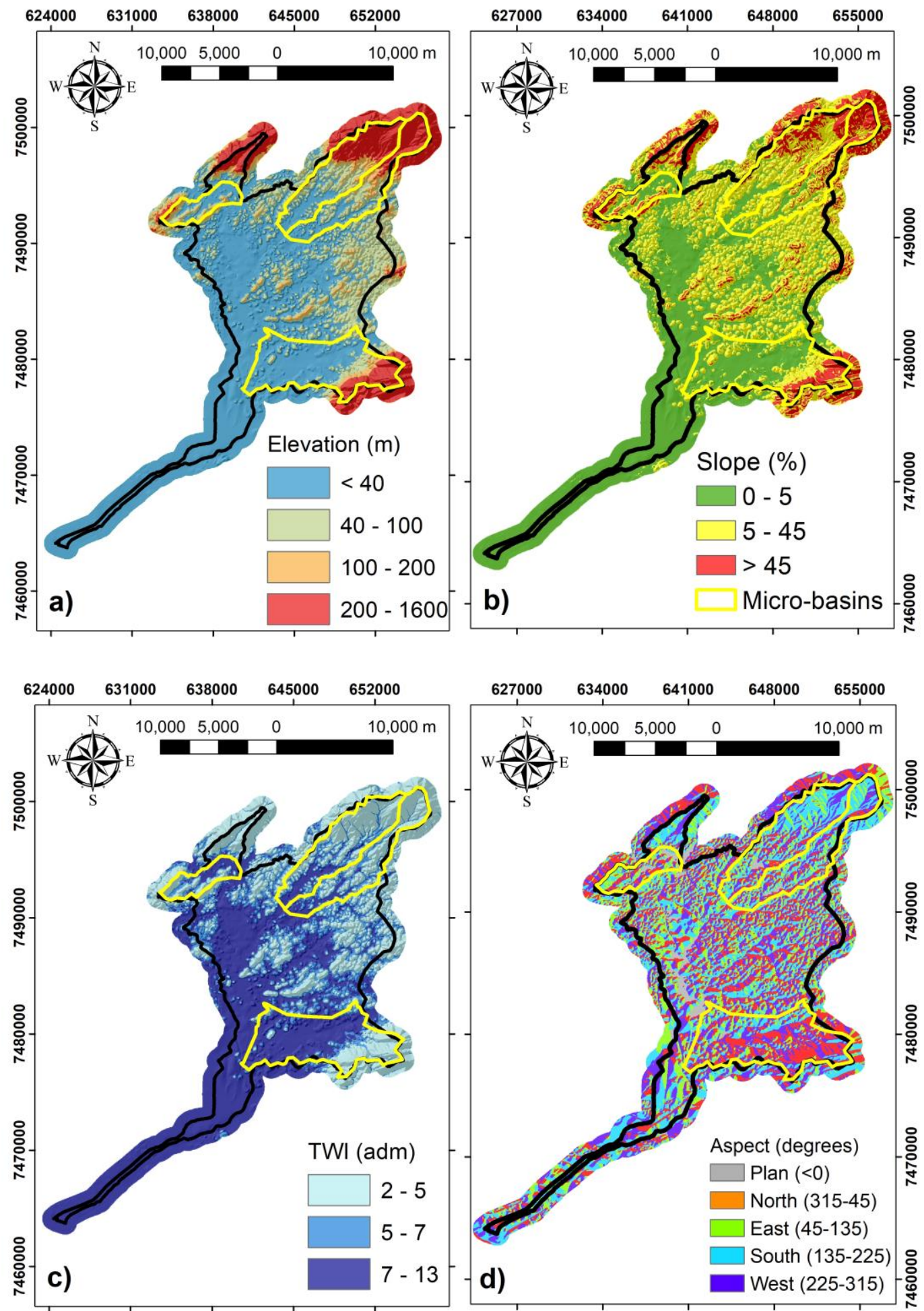

Figure 2. Thematic maps created to represent morphometric parameters related with soil and relief criteria to select the priority areas. a) elevation (m); b) slope (\%), c) topographic wetness index (dimensionless), d) aspect (degrees) 


\section{I Macrothink}

The Figure 3.a presents the simplified soil map classified according to the map units identified on the field campaign. The land use cover map was simplified according the presence of natural vegetation and intensity of management, gathering legacy data with field observations (Figure 3.b).
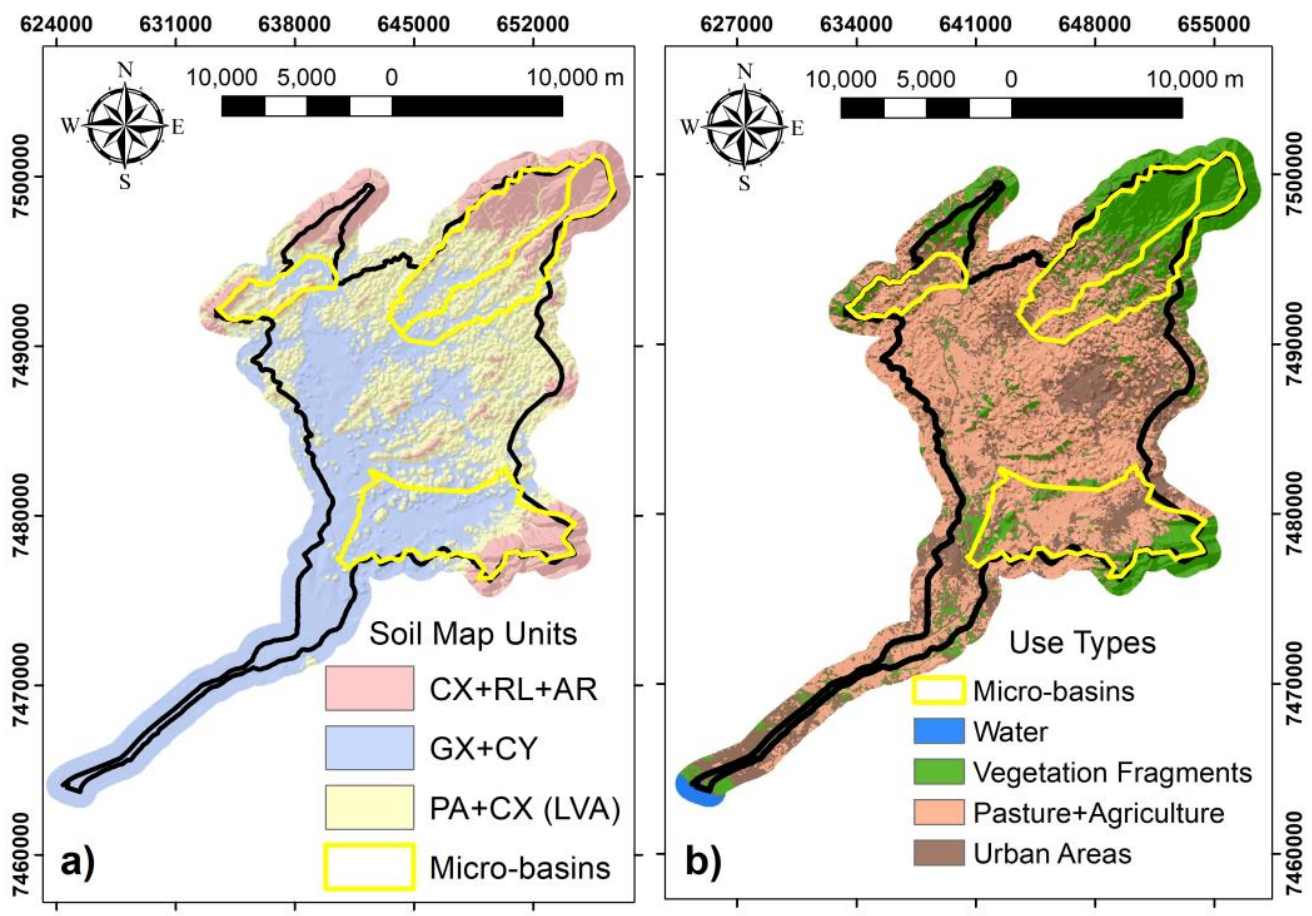

Figure 3. Thematic maps created to represent a) soil map units; and b) simplified land use cover

The thematic maps created (Figure 3) and numerical surface models (Figure 2) were combined by map algebra procedure according to the evaluation matrix to select priority areas to water provision and environmental conservation (Table 2).

The approach based on the proposed criteria, considering legacy data, geoprocessing tools, field data and tacit knowledge from multidisciplinary team, allowed to select priority areas for interventions in favor of the conservation of natural water resources and environmental preservation in the BHCRG, as presented at the Figure 4. 


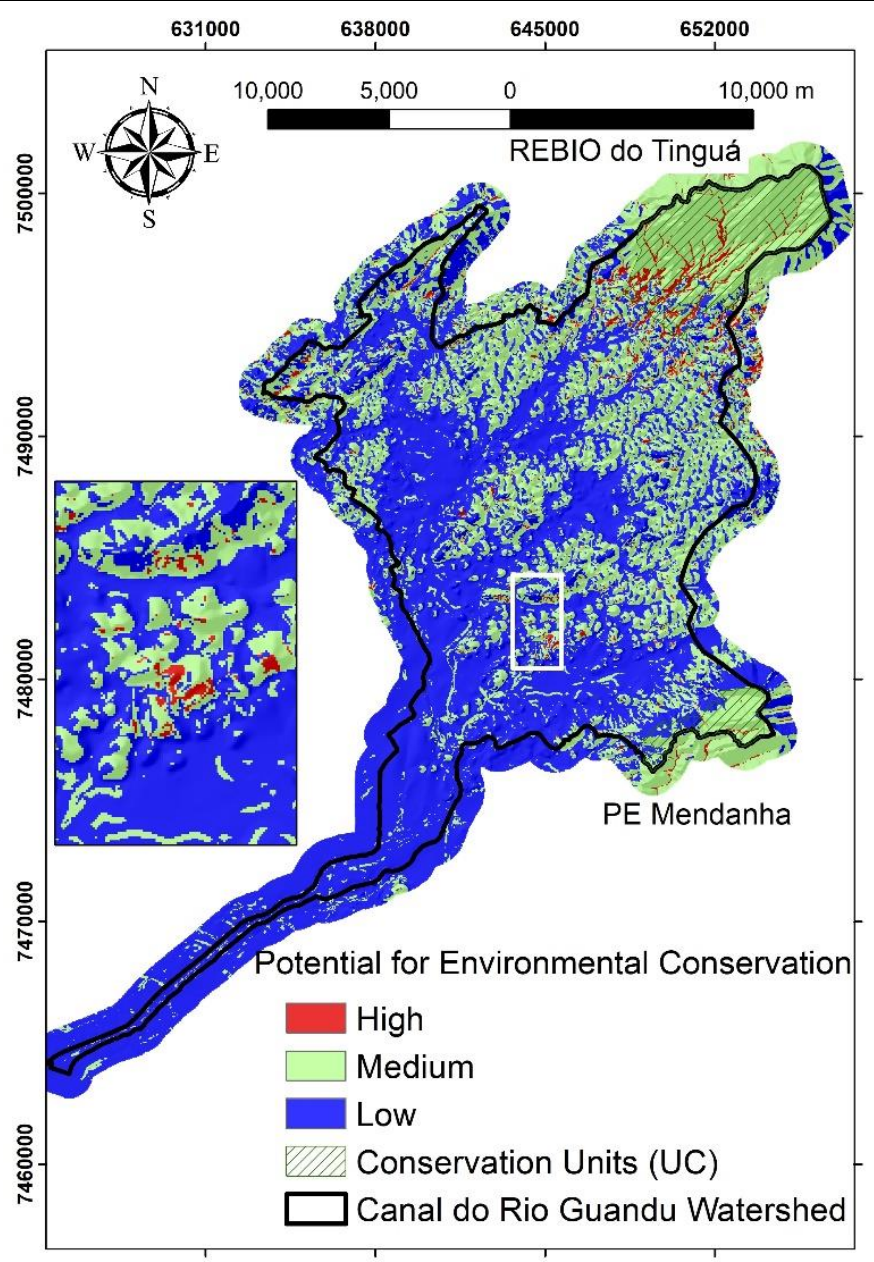
2021, Vol. 9, No. 1

Figure 4. Classification of priority areas to water provision and environmental conservation, highlighting the protected areas designed by Brazilian law (PE Mendanha and REBIO do Tinguá)

\section{Discussion}

The flooding risks at large watersheds can be underestimated if the only parameter adopted is the size of catchment area (Aparna et al, 2015). It is due the difficulty to the water contribution occur throughout the full catchment area at one time. However, Mesquita et al. (2017) agreed that this parameter is essential to understand possible scenarios according to hydrological behavior.

In other hand, Lima (2010) supports that the management effects are more noticeable in smaller watersheds, due the intense effect along the drainage channels, in this sense, large watersheds are not able to reflect the management effects. The four micro-basins used to further research presents catchment area and perimeter significantly smaller than the BHCRG (Table 3), and in this case, show reasonable possibility to control and understand the effect of management over the hydrological characteristics

The Dd indicates the drainage system efficacy (Rai et al, 2017a; Aher et al., 2014), and represents the inverse relation of rivers length, where high values to drainage density are 
related with small length of the contributing tributaries (Calil et al., 2012). The average Dd of BHCRG and selected micro-basins was $2,84 \mathrm{~km} / \mathrm{km}^{2}$ showing medium drainage, which respect the range of this index at Rai et al. (2017b) research that ranged between $1,5 \mathrm{~km} / \mathrm{km}^{2}$ (medium drained watersheds) to $3,2 \mathrm{~km} / \mathrm{km}^{2}$ (highly drained watersheds).

The Ir values to the BHCRG, MBH1 and MBH2 were higher than the other micro-basins (Table 3) showing a higher probability of degradation and flooding once they present remarkable variability regarding topographic parameters, and a wide variation between the headspring and the local base level associated with the dense drainage network.

Morphological parameters of the hydrographic basins allowed inferring about the hydrological system functioning of a terrain unit for water resources management purposes. By analyzing the area and perimeter factors only, the smaller micro-basins of the BHCRG present the better possibilities of controlling the hydrological factors by management actions, if more than $20 \%$ of the area is managed (Lima, 2010).

In micro-basins with high drainage densities, as verified in $\mathrm{MBH}$, rainwater can flow quickly to the drainage channels, remaining only a short time in the system, which can lead to intermittent drainage. These regions require actions that promote an improvement in the soil infiltration, also causing an increase of the time of concentration of the water in the system, and consequently, a perennially of the rivers downstream. Evaluating the maintenance coefficient, it is worth mentioning that $\mathrm{MBH} 3$ presents the smallest area required to maintain a perennial fluvial course among the micro-basins selected, suggesting that the MBH3 has lower potential for management of water resources.

$\mathrm{MBH} 1$ and $\mathrm{MBH} 2$ presents wide variability regarding relief and high roughness indexes, the surface runoff process is more pronounced, which makes the regions more susceptible to reach sedimentation levels at the transmission channels, causing decreasing in water resource quality and quantity. In these basins, the knowledge about velocity of surface flow downstream is important regarding the effects of laminar erosion, aiming to increase the soil infiltration capacity.

The hydrological behavior suggests specific intervention actions for each basin in order to improve the sustainability and quality of water resources (Aher et al. 2014). Management actions that prioritize the increase of rain infiltration and sediment retention will promote a slower release to the drainage channels, increasing the time of water concentration in the soil and consequently improvement of local water resources (Leite et al., 2009; Pinheiro et al., 2009). The most common indicated to promote these conditions are the preservation of native forests, reforestation with perennial species, and conservationist agricultural practices (Honda and Durigan, 2017).

The landscape conditions play a decisive role at the soil drainage variability. The relief seems to be important in the successional stage in which the fragments of the vegetation are found, so that hilly areas retain the few fragments in an advanced regeneration stage, mainly due the difficult to use those areas to pasture or agriculture purposes.

The protected areas, as the Tinguá Biological Reserve (REBIO Tinguá) and the Mendanha 
State Park (PE Mendanha) host most part of conserved and diversified forest fragments, presenting a forest structure with three distinct strata. All strata present typical species from ARF that occurs naturally in the region as remaining fragments hosting also important specimens of local fauna.

Rocky outcrops occur at the water divisors, particularly between Nova Iguaçu and Queimados municipalities, conditioning young soils as Leptosols and Cambisols. Colluvial soils (Planosols and Gleysols) were also found in low areas, due the influence of drainage.

The BHCRG have predominance of lowlands and floodplains, presenting about a third of its soils under imperfect or more severe drainage conditions. The vegetation presents generally in the initial stages of succession, some areas in the middle stage, and few at advanced stage of regeneration. In the highlands the natural vegetation fragments are well preserved, particularly under hilly slopes. The scarcity of riparian forests is remarkable, as seen in the field campaigns, serving as a proper measurement tool to analyze an obvious problem related to water quality and environmental preservation. Great part of area is already occupied by urban expansion and rural areas with unfruitful pastures among small agricultural areas. There are also areas with irregular activities (rock and sand exploitation), serving to the growing urbanization and expansion of industrial parks, which have been installed in order to the logistics advantages presented by the region due the accessibility.

Thus, there are high elevation and well vegetated portions of the area, particularly preserved at the Tinguá Biological Reserve (REBIO do Tinguá) where there is a water station (CEDAE Rio D'Ouro). These areas provide good quality water; on the other hand, was observed at field campaigns the scarcity of natural vegetation at undeveloped terraces of the Guandu River, and its tributaries, which are responsible for supplying Guandu Water Treatment Station (ETA Guandu). The ETA Guandu station supplies the population of the Rio de Janeiro City and neighbors that overpass 8 million inhabitants (Castro \& Ferreirinha, 2012).

The approach based on simple criterias and parameters easy to observe in situ, allied with geoprocessing tools allowed to classify the BHRCG watershed according priority to water provision and environmental conservation. Furthermore, the proposed rules can also be tested in other watershed with similar landscape conditions, once the micro-basin selected were representative from the BHRCG watershed conditions, suggesting that the method purposed could be used in a multi-scale approach.

The analytical procedures addressed the goals, comprising the hydrologic characterization, and the selection of priority areas for management interventions. These areas do not have established vegetation, or are protected by Brazilian law, or even with urban occupation. In this sense, the areas classified as high priority could have better land use and management in order to preserve water resources and better environmental conservation. Analogously, the areas that present low priority are placed at urban areas, or floodplains with hydromorphic soils, unfavorable for establishment of vegetation or management actions. However, it is important to highlight that part of this areas, including preservation areas (APP) placed at the Guandu river's terrace, frequently show irregular urban occupation. 
It was possible to observe according to the final map (Figure 4), that, in general, the soil and relief characteristics induce an average potential to vegetation establishment, due the hilly slopes and shallow soils. Nevertheless, when correlating the priority classes with areas already protected by Brazilian law (UC and APP) it stands out as a high potential intervention in areas from the damping zones (surrounding natural parks), which should be encouraged the creation of forests with low management intensity and ecological corridors connecting forested fragments. In these regions, water resources management becomes relevant and governmental programs related to the preservation of vegetation and water provision should be promoted by the water agencies and regional committees.

\section{Conclusion}

The assessment of watershed morphometrical parameters pointed out that $\mathrm{MBH} 3$ presents the smallest area required to maintain a perennial fluvial course, suggesting that this is a priority area for management of water resources. In general, for the other micro-basins further regarding laminar erosion should be performed aiming to increase the soil infiltration capacity.

The map of priority areas to water provision and environmental conservation highlighted as high potential the damping zones (surrounding natural parks and preservation areas), in which could be created ecological corridors connecting forested fragments providing better conditions to vegetation establishment and soil infiltration.

The approach based on simple criteria based on parameters easy to observe in situ, with the support of geoprocessing tools, topographical and legacy data, satisfactorily classified priority areas to water provision and environmental conservation at the study area.

\section{Acknowledgments}

We thank the Federal Rural University of Rio de Janeiro - UFRRJ and Brazilian Agricultural Research Corporation - EMBRAPA. We recognize Paraíba do Sul River Basin Agency AGEVAP for the financial support.

\section{References}

Aher, P. D., Adinarayana, J., \& Gorantiwar, S. D. (2014). Quantification of morphometric characterization and prioritization for management planning in semi-arid tropics of India: A remote sensing and GIS approach. Journal of Hydrology, 511, 850-860. https://doi.org/10.1016/j.jhydrol.2014.02.028

Alves, J. M. D. P., \& Castro, P. D. T. A. (2016). Influência de feições geológicas na morfologia da bacia do rio do Tanque (MG) baseada no estudo de parâmetros morfométricos e análise de padrões de lineamentos. Revista Brasileira de Geociência, 33(2), 117-124. https://doi.org/10.25249/0375-7536.2003332117124

Aparna, P., Nigee, K., Shimna, P., \& Drissia, T. K. (2016). Quantitative analysis of geomorphology and flow pattern analysis of Muvattupuzha River Basin using Geographic Information system. Aquatic Procedia, 4, 609-616. 
https://doi.org/10.1016/j.aqpro.2015.02.079

Arias, P. A., Martínez, J. A., \& Vieira, S. C. (2015). Moisture sources to the 2010-2012 anomalous wet season in northern South America. Climate dynamics, 45(9-10), 2861-2884. https://doi.org/10.1007/s00382-015-2511-7

Ayalew, G., \& Selassie, Y. G. (2015). Soil loss estimation for soil conservation planning using geographic information system in Guang watershed, Blue Nile basin. J. Environ. Earth Science, 5, 126-134.

Bagstad, K. J., Semmens, D. J., Waage, S., \& Winthrop, R. (2013). A comparative assessment of decision-support tools for ecosystem services quantification and valuation. Ecosystem Services, 5, 27-39. https://doi.org/10.1016/j.ecoser.2013.07.004

Banco de Dados Geográficos do Exército - BDGEx. (2011). Retrieved from https://bdgex.eb.mil.br.

Brancalion, P. H., Garcia, L. C., Loyola, R., Rodrigues, R. R., Pillar, V. D., \& Lewinsohn, T. M. (2016). A critical analysis of the Native Vegetation Protection Law of Brazil (2012): updates and ongoing initiatives. Natureza \& Conservação, 14, 1-15. https://doi.org/10.1016/j.ncon.2016.03.003

BRASIL. Resolução CONAMA nº 006, de 4 de maio de 1994. (1994). Diário Oficial da União, Brasília, DF.

Bueno, M. M., Valcarcel, R., Pereira, M. G., \& Mateus, F. A. (2020). Sustainable provision of raw water based on the management of ecosystem services in small watersheds. Revista Ambiente \& Água, 15(2). https://doi.org/10.4136/ambi-agua.2439

Calil, P. M., Oliveira, L. F. C., Kliemann, H. J., \& Oliveira, V. A. (2012). Caracterização geomorfométrica e do uso do solo da Bacia Hidrográfica do Alto Meia Ponte, Goiás. Revista Brasileira de Engenharia Agrícola e Ambiental, 16(4), 433-442. https://doi.org/10.1590/S1415-43662012000400014

Castro, C. M., \& Ferreirinha, M. M. (2012). A problemática ambiental na bacia hidrográfica do rio Guandu: desafios para a gestão dos recursos hídricos. Anuário do Instituto de Geociências, 35(2), 71-77. http://dx.doi.org/10.11137/2012_2_71_77

Empresa Brasileira de Pesquisa Agropecuária - Embrapa geodatabase. (2013). Retrieved from https://www.embrapa.br.

Honda, E. A., \& Durigan, G. (2017). A restauração de ecossistemas e a produção de água. Hoehnea, 44(3), 315-327. https://doi.org/10.1590/2236-8906-82/2016

IBGE - Instituto Brasileiro de Geografia e Estatística. (2012). Manual Técnico da Vegetação Brasileira: sistema fitogeográfico, Inventário das formações florestais e campestres - Técnicas e manejo de coleções botânicas e procedimentos para mapeamentos (2nd ed.). Rio de Janeiro, RJ: IBGE.

IBGE - Instituto Brasileiro de Geografia e Estatística. (2015). Manual técnico de pedologia. 
Coordenação de Recursos Naturais e Estudos Ambientais (3rd ed.). Rio de Janeiro, RJ: IBGE.

Instituto Brasileiro de Geografia e Estatística - IBGE. (2010). Retrieved from https://www.ibge.gov.br/geociencias-novoportal/downloads-geociencias.html.

IUSS Working Group WRB. (2014). World reference base for soil resources. World Soil Resources Reports 106. Rome: Food and Agriculture Organization of the United Nations.

Leite, M. H. S., Couto, E. G., Amorim, R. S. S., Costa, E. L., \& Maraschin, L. (2009). Perdas de solo e nutrientes num Latossolo Vermelho-Amarelo ácrico típico, com diferentes sistemas de preparo e sob chuva natural. Revista Brasileira de Ciência do Solo, 33, 689-699. https://doi.org/10.1590/S0100-06832009000300021

Lima, W. P. (2010). A silvicultura e a água: ciência, dogmas, desafios. Cadernos do Diálogo, 1, 1-68. Rio de Janeiro, RJ: Instituto BioAtlânica.

Mello, K., Costa, D. R., Valente, R. A., \& Vettorazzi, C. A. (2018). Multicriteria Evaluation for Protected Area Definition Aiming at Water Quality Improvement. Floresta e Ambiente, 25(3). https://doi.org/10.1590/2179-8087.013416

Mesquita, A. R., Macedo, R. P., Lopes, M. S., Souza, T. D., \& Menini, S. E. (2017). Análise morfométrica da bacia hidrográfica do córrego Manhuaçuzinho, Minas Gerais. Enciclopédia Biosfera, 14(25), 22. https://doi.org/10.18677/EnciBio_2017A4

Ministério do Meio Ambiente - MMA. (2019). Retrieved from www.mma.gov.br/areas-protegidas.

Mora, F. (2019). The use of ecological integrity indicators within the natural capital index framework: The ecological and economic value of the remnant natural capital of México. Journal for nature Conservation, 47, 77-92. https://doi.org/10.1016/j.jnc.2018.11.007

Neto, T. D. A. C., Camara, R., Anjos, L. H. C., Correia, M. E. F., Pereira, M. G., \& Jaccoud, C. F. S. (2018). Relação fauna do solo-paisagem em plantio de eucalipto em topossequência. Floresta, 48(2), 213-224. http://dx.doi.org/10.5380/rf.v48i2.55041

Oliveira, R. G., Bacani, V. M., Silva, V. R., Cunha, E. R., \& Ferreira, E. M. (2012). Análise da fragilidade ambiental da bacia hidrográfica do córrego São João-MS utilizando geoprocessamento. Revista Brasileira de Cartografia, 64(1).

Padilha, A. F., Gobatto, D. R., \& Batistella, D. (2017). Estimativa da aptidão agrícola de terras por álgebra de mapas. Os Desafios da Geografia Física na Fronteira do Conhecimento, 1, 5661-5668. https://doi.org/10.20396/sbgfa.v1i2017.2253

Pezzopane, J. E. M., Oliveira, N. S. N., \& Vilela, M. F. (2001). Risco de incêndios em função da característica do clima, relevo e cobertura do solo. Floresta e Ambiente, 8(1),161-165.

Pinheiro, A., Teixeira, L. P., \& Kaufmann, V. (2009). Capacidade de infiltração de água em solos sob diferentes usos e práticas de manejo agrícola. Revista Ambiente e Água, 4, 188-199. https://doi.org/10.4136/ambi-agua.97 
Rai, P. K., Mishra, V. N., \& Mohan, K. (2017a). A study of morphometric evaluation of the Son basin, India using geospatial approach. Remote Sensing Applications: Society and Environment, 7, 9-20. https://doi.org/10.1016/j.rsase.2017.05.001

Rai, P. K., Mohan, K., Mishra, S., Ahmad, A., \& Mishra, V. N. (2017b) A GIS-based approach in drainage morphometric analysis of Kanhar River Basin, India. Applied Water Science, 7(1), 217-232. https://doi.org/10.1007/s13201-014-0238-y

Santos, H. G., Jacomine, P. K. T., Anjos, L. H. C., Oliveira, V. A., Lumbreras, J. F., Coelho, M. R. et al. (2018). Sistema brasileiro de classificação de solos. (5rd ed.) Rio de Janeiro: Embrapa Solos.

Scarano, F. R., \& Ceotto, P. (2015). Brazilian Atlantic forest: impact, vulnerability, and adaptation to climate change. Biodiversity and Conservation, 24(9), 2319-2331. https://doi.org/10.1007/s10531-015-0972-y

Schumm, S. A. (1956). Evolution of drainage systems and slopes in badlands of Perth Amboy. Geological Society of America Bulletin, 6, 597-646. https://doi.org/10.1130/0016-7606(1956)67[597:EODSAS]2.0.CO;2

Silveira, G. R. P., Campos, S., Gonçalves, A. K., Barros, Z. X., \& Pollo, R. A. (2015). Geoprocessamento aplicado na espacialização da capacidade de uso do solo em uma área de importância agrícola. Energia na Agricultura, 30(4), 363-371. https://doi.org/10.17224/EnergAgric.2015v30n4p363-371

Sistema de Informação Geográficas e Geo-ambientais das Bacias Hidrográficas dos Rios Guandu, Da Guarda e Guandu-Mirim - SIGA-Guandu. (2010) Retrieved from http://54.94.199.16:8080/siga-guandu/map

Vettorazzi, C. A., \& Valente, R. A. (2016). Priority areas for forest restoration aiming at the conservation of water resources. Ecological Engineering, 94, 255-267. https://doi.org/10.1016/j.ecoleng.2016.05.069

\section{Copyrights}

Copyright for this article is retained by the author(s), with first publication rights granted to the journal.

This is an open-access article distributed under the terms and conditions of the Creative Commons Attribution license (http://creativecommons.org/licenses/by/4.0/) 